\title{
Hospital acquired computervirus infections
}

\section{Isaacs, D A Fitzgerald, H A Kilham}

Children's Hospital at Westmead, Locked Bag 4001, Westmead, NSW 2145, Australia

D Isaacs

D A Fitzgerald

H A Kilham

Correspondence to:

Prof. Isaacs

david@chw.edu.au

Accepted 20 August 2001

\section{Definition} acquired in hospitals (see fig 1 ).

\section{Aetiology} tion, and extreme provocation.
The hospital acquired computerviruses or HACs have been defined as computerviruses

The origin of computerviruses is unknown, although they are thought to have evolved from the coxsackieviruses by a process of mutation, rotation, recombination, translocation, disloca-
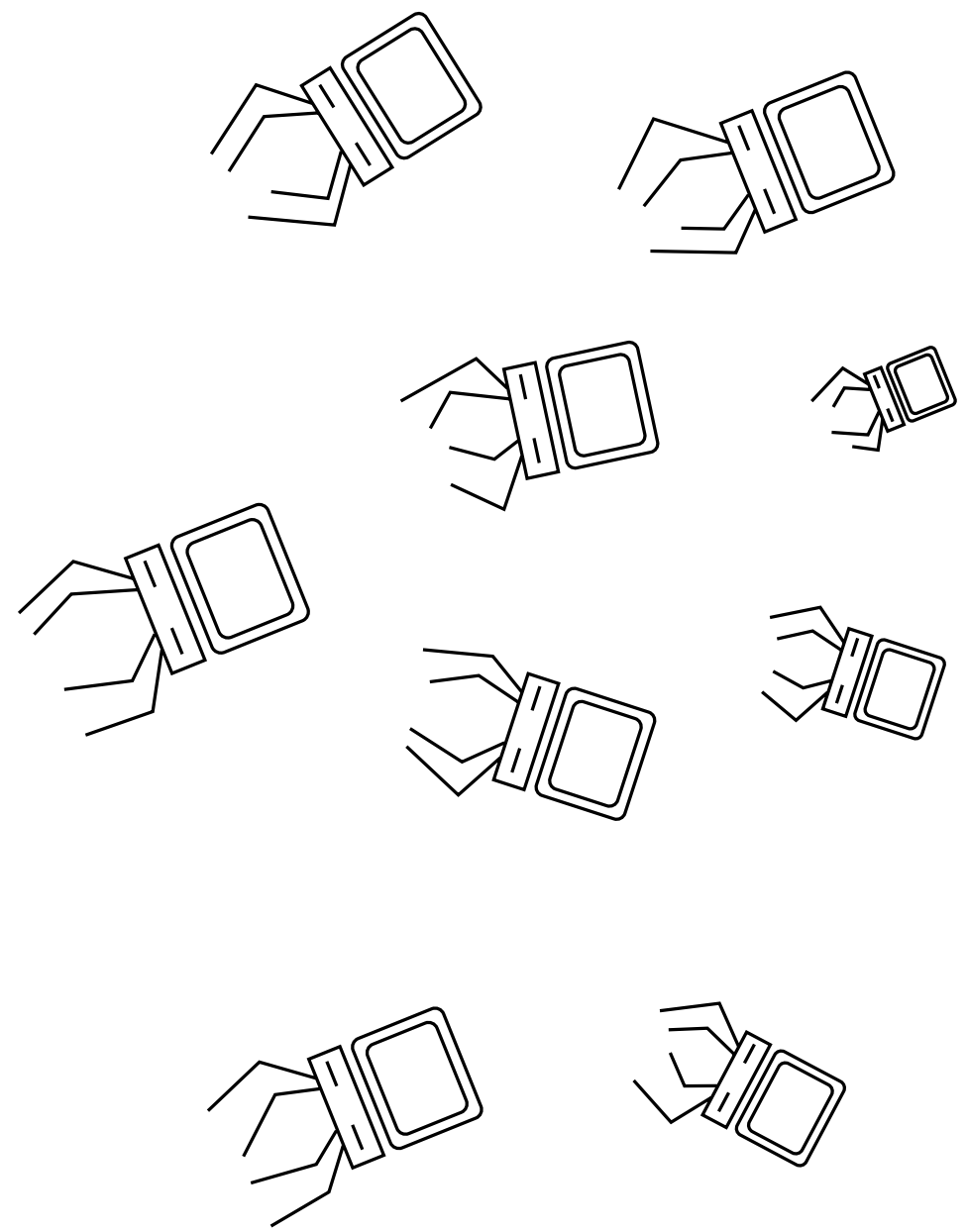

Figure 1 A swarm of computerviruses.

\section{Epidemiology}

It was the best of times, it was the worst of times.

\section{Pathogenesis}

Computerviruses were cast forth upon the airwaves and upon the seawaves and upon the brainwaves. And some fell on hard disks and some fell on soft disks. But all were corrupted.

\section{Clinical features}

The hospital acquired computerviruses cause a severe diskitis with diffuse, widespread information.

Table 1 shows the different strains of computerviruses and their clinical features.

\section{Treatment}

The only agent with limited antiviral activity against the computerviruses is unicyclovir, which is altered by the computer to the active metabolites bicyclovir, tricyclovir, and recyclovir.

\section{Prevention}

There is a vaccine made from organisms which are barely alive but attenuated, such as hospital administrators.

Table 1 Computerviruses and their clinical features

\begin{tabular}{ll}
\hline Computer virus & Clinical features \\
\hline Finance Department Virus (FDV) & $\begin{array}{l}\text { Flashes message: "Your } \\
\text { Department has spent } \\
\text { money. This is an } \\
\text { ILLEGAL } \\
\text { OPERATION" }\end{array}$ \\
$\begin{array}{ll}\text { Flashes message: } \\
\text { "Insufficient memory" } \\
\text { Emeritus Professor Virus (EPV) } & \begin{array}{l}\text { Flashes message: "Needs } \\
\text { re-booting" }\end{array} \\
\text { Orthotics Virus (OV) } & \begin{array}{l}\text { No message. Screen goes } \\
\text { blank }\end{array} \\
\text { Committee Virus (CV) } & \begin{array}{l}\text { Flashes lights } \\
\text { Flashes!! Displays } \\
\text { message: "Hard disk too } \\
\text { Migraine Virus (MV) }\end{array} \\
\text { floppy. Take Viagra" } \\
\text { Flashes message: "Scan } \\
\text { repeatedly until broke" } \\
\text { Radiology Virus (RV) } & \begin{array}{l}\text { Flashes message: "Do } \\
\text { you want to save?" }\end{array} \\
\text { Intensive Care Virus (ICV) } & \begin{array}{l}\text { Flashes message: "A fatal } \\
\text { error has occurred" }\end{array} \\
\text { Pathology Department Virus (PDV } & \text { Flashes message: "You } \\
\text { have exited" }\end{array}$ \\
\hline Mortuary Virus (MV) & \\
\hline
\end{tabular}

